\title{
Manuel Gamio e seu projeto indigenista para o México e a América Latina através dos periódicos Ethnos e América Indígena (1920-1960)
}

\author{
Natally Vieira Dias ${ }^{1}$ \\ Nathália Alves Louzada Boaventura ${ }^{2}$
}

\begin{abstract}
Resumo: Manuel Gamio é uma figura bastante conhecida do cenário intelectual latino-americano, tendo sido um dos principais construtores ideológicos do indigenismo mexicano pós-revolucionário. Os estudos sobre seu pensamento se baseiam, em geral, em sua obra Forjando patria, publicada em 1916, e envolvem apenas o contexto mexicano. A atuação de Gamio como editor de revistas - papel cumprido por ele durante boa parte de sua trajetória - e a faceta latino-americanista de seu projeto indigenista são questões pouco estudadas. Este artigo explora ambas as dimensões a partir da análise dos editoriais produzidos por Gamio à frente das revistas Ethnos, entre 1920 e 1925, quando encabeçava a Dirección de Antropología no México; e América Indígena, entre 1942 e 1960, durante sua gestão como diretor do Instituto Indigenista Interamericano. O caráter específico da "forma revista" (SARLO, 1992) a torna uma fonte privilegiada para resgatar a atuação político-intelectual de Gamio nesses dois contextos e nos cenários nacional e continental.
\end{abstract}

Palavras-chave: Manuel Gamio; História Intelectual; revistas intelectuais.

\section{Manuel Gamio and his indigenist project for Mexico and Latin America in the periodicals Ethnos and América Indígena} (1920-1960)

Abstract: Manuel Gamio is well-known in the Latin American intellectual scene. He has been one of the most important ideological makers of the post-revolutionary Mexican indigenismo. The studies of his ideas are generally based upon his work Forjando Patria, published in 1916, and also restricted to Mexican context. Both Gamio's actuation as periodical editor - a role he played during his intellectual journey - and the Latin-Americanst facet of his indigenist project are poorly studied issues. The current article explores both dimensions analyzing the editorials that Gamio produced when he was guiding Ethnos periodical, between 1920 and 1925, when he leaded the Dirección de Antropología in Mexico; and América Indígena, between 1942 and 1960, during his tenure as director of the Inter-American Indian Institute. The specific feature of the "periodical format" (SARLO, 1992) makes it a privileged source to investigate

\footnotetext{
${ }^{1}$ Doutora em História pela UFMG. É professora adjunta da Universidade Estadual de Maringá (UEM). E-mail: natyvdias@gmail.com

${ }^{2}$ Mestranda em História pela UFMG, com a pesquisa intitulada Forjando patria: indigenismo e atuação político-intelectual de Manuel Gamio na Dirección de Antropología (1916-1924), com financiamento da CAPES. E-mail: cl.nathalia.historia@gmail.com
} 
Gamio's political-intellectual actuation in both these two historical contexts and in the national and continental scene.

Key-Words: Manuel Gamio; Intellectual History; intellectual maganizes.

Artigo recebido em: 28/07/2020

Artigo aprovado para publicação em: 28/12/2020

\section{Indigenismo e revistas}

O indigenismo é um dos fenômenos político-intelectuais mais importantes surgidos na América Latina. Seu desenvolvimento no século XX esteve intimamente ligado a uma crise de legitimidade dos modelos culturais europeus e ganhou potência a partir do processo de construção das identidades nacionais, manifestando-se em movimentos sociais, artísticos e intelectuais.

Henri Favre (1998) o considera, sobretudo, como uma corrente de pensamento favorável aos indígenas. Analisando suas manifestações na longa duração, localiza suas origens desde os primeiros contatos que os europeus estabeleceram com os povos nativos. Favre ressalta que a partir da segunda metade do século XIX, momento em que os países latino-americanos buscavam construir-se enquanto nações, o indigenismo desenvolveu-se como um movimento ideológico de expressão política, social, literária e artística, que situou os povos indígenas no contexto da problemática nacional. (FAVRE, 1998, p. 7-8)

Na mesma linha de Favre, o antropólogo mexicano Félix Báez-Jorge (1993), ao examinar as chaves ideológicas do indigenismo latino-americano, afirma que, em sentido restrito, ele poderia ser definido como um conjunto de políticas que visavam promover melhorias materiais e sociais direcionadas às comunidades nativas, atuando como uma ferramenta que possibilitaria sua integração às formações nacionais. Em grande medida estruturadas a partir da Antropologia, estas políticas evidenciavam uma preocupação de setores governamentais em elevar as condições de vida dos grupos indígenas, em um impulso civilizador que frequentemente desconsiderava os interesses destes povos. Em sentido mais amplo, ressalta o caráter polissêmico e multifacetado do 
conceito, que diz respeito a uma pluralidade de pensamentos e expressões. (BÁEZ-JORGE, 1993, p. 17)

É preciso destacar, como apontam Luis Villoro (1996, p. 8) e Michiel Baud (2003, p. 65), que o indigenismo foi, sobretudo, um movimento ou um conjunto de concepções de não indígenas, que buscaram representar, refletir e/ou atuar em favor dos indígenas. Isso significa assumir que, em muitos casos, as demandas étnicas, sociais e os interesses das próprias comunidades indígenas foram ignorados.

Como observa Favre (1998), o auge político do indigenismo ocorreu entre as décadas de 1920 e 1970, quando este se tornou um dos principais meios utilizados pelos Estados latino-americanos para fomentar nacionalidades, convertendo-se, em certos casos, em uma doutrina oficial. Isso, sem dúvida, foi o que ocorreu no caso do México pós-revolucionário. Portanto, analisar o indigenismo mexicano pressupõe assumir que seu objetivo enquanto prática política foi o de construir e manter uma ideologia de Estado intrinsecamente ligada ao nacionalismo e com fortes consequências sobre os grupos indígenas. (SILVA, 2012, p.19)

No caso mexicano, a Revolução iniciada em 1910 evidenciou questões seculares e fez emergir grandes transformações simbólicas marcadas pela afirmação das especificidades latino-americanas e pela valorização do passado indígena do país, o que embasou o fomento de uma identidade nacional mestiça e culminou numa forte política cultural nacionalista. As efervescências políticas e sociais estimularam muitos debates, especialmente no que dizia respeito à realização de projetos que integrassem o setor rural, predominantemente indígena. A necessidade de delimitarem-se referenciais simbólicos aliada à constatação da heterogeneidade que caracterizava o país fizeram com que o discurso da integração cultural fosse tido como a grande alternativa para fomentar um projeto de nacionalidade capaz de construir uma nova ordem social.

Como mostra Antônio Carlos Amador Gil (2007, p.18), o processo revolucionário teve como um dos desdobramentos mais significativos o desenvolvimento de uma ideologia na qual o mestiço passou a ser visto como o 
elemento definidor da identidade nacional. ${ }^{3}$ Os debates pautados pelo ideal de miscigenação ressignificaram o passado pré-hispânico e os conceitos raciais pessimistas relacionados aos indígenas. Reivindicando algo próprio do continente, esforçaram-se em valorizar a mistura de raças como positiva e necessária à construção de uma unidade nacional. Essa concepção ideológica, no entanto, se baseou na ideia de um passado indígena glorioso, ao passo que os índios contemporâneos deveriam ser transformados e incorporados à modernidade e à nova vida nacional. (BÁEZ LANDA, 2009, p. 56)

Emilio Kourí (2010) destaca que a Revolução e o desenvolvimento de estudos ligados à Antropologia deram ao indigenismo mexicano um significado próprio, público e institucional. (KOURÍ, 2010, p. 419-420) Ao se estabelecer na esfera política mexicana nas primeiras décadas do século XX, a Antropologia passou a embasar cientificamente as políticas indigenistas. Constituiu-se como um campo de estudo da alteridade, que analisaria o ordenamento da realidade e atuaria como um instrumento orientado para a resolução dos problemas sociais, identificando insuficiências e atrasos que impediam a formação da nacionalidade.

Portanto, a análise do indigenismo e, sobretudo, do indigenismo oficial mexicano deve partir de sua configuração enquanto discurso e prática de caráter, ao mesmo tempo político e ideológico. Nesse sentido, compreender essa experiência indigenista passa necessariamente pelo estudo da atuação dos intelectuais que assentaram as bases desse pensamento e que tiveram grande influência no delineamento das instituições e políticas públicas voltadas aos povos indígenas promovidas pelo Estado mexicano ao longo do século XX.

Sem dúvida alguma, o antropólogo e arqueólogo Manuel Gamio Martínez (1883-1960) se apresenta como uma das figuras centrais intelectuais a serem estudadas para a compreensão do indigenismo, tendo em vista seu papel central como um de seus

\footnotetext{
${ }^{3}$ Matizando o processo de continuidade dessa ideologia e ressaltando o campo de disputas em torno da questão indígena, Antônio Carlos Amador Gil destaca que a formação de uma ideologia da mestiçagem já estava presente no período porfirista, mas ganhou amplitude a partir da Revolução, ao recuperar noções criollas de identidade e agregar o grupo dos mestiços (GIL, 2007, p. 18).
} 
principais ideólogos no México e no continente. Gamio atuou à frente de importantes instituições ligadas ao tema nos âmbitos mexicano e continental. Em 1917, encabeçou a Dirección de Antropología no México, órgão fundamental para o desenvolvimento das políticas indigenistas do país, e, durante as décadas de 1940 e 1950, dirigiu o Instituto Indigenista Interamericano, então sediado na Cidade do México.

Apesar de a figura de Manuel Gamio ser bastante conhecida na América Latina, normalmente seu pensamento é estudado através de sua principal obra, Forjando Patria: pro nacionalismo, que foi publicada em 1916 e reúne artigos escritos anteriormente. Ao se tratar das ideias e ação política de Gamio, pouco espaço tem sido dado a seu papel como editor de publicações periódicas, o que foi concomitante aos postos oficiais que ele exerceu durante várias décadas no contexto mexicano e latino-americano. Nesse sentido, consideramos de fundamental importância o resgate de sua atuação político-intelectual por meio das publicações periódicas para a compreensão do projeto indigenista que o intelectual mexicano esboçou não apenas para o México, mas para toda a América Latina. Dessa forma, este artigo analisa as intervenções intelectuais de Manuel Gamio enquanto diretor das revistas Ethnos: Revista Mensual para la vulgarización de estudios antropológicos sobre México y Centro-América ${ }^{4}$ (1920-1923), publicada quando ele encabeçava a Dirección de Antropología no México (1917-1924), e América Indígena: órgano trimestral del Instituto Indigenista Interamericano, que Gamio dirigiu durante o período em que foi o diretor do Instituto, de 1942 a 1960.

As revistas criadas e produzidas por intelectuais têm se mostrado como fontes históricas de grande relevância para se estudar o desenvolvimento de ideias políticas e

\footnotetext{
${ }^{4}$ Ethnos foi publicada de 1920 a 1925 e, de acordo com seus idealizadores, contou com "três épocas", sendo a primeira de abril de 1920 a março de 1921. Sobre a segunda e terceira épocas, encontramos menos informações, mas, ao que tudo indica, a segunda foi de novembro de 1922 a abril de 1923 e a terceira teve três edições, todas no ano de 1925: uma referente aos meses de janeiro e fevereiro; outra de março e abril e a última edição da revista foi, possivelmente, a publicada em maio de 1925. Durante a segunda época, a revista teve seu nome alterado para Ethnos: revista dedicada al estudio y mejoría de la población indigena de México e os editores justificaram a mudança pela necessidade de colocar mais ênfase no "problema indígena".
} 
sociais, os embates travados em torno delas e a formação de redes intelectuais, tanto em contextos nacionais quanto transnacionais, como demonstra a significativa produção acadêmica sobre o tema realizada nas últimas décadas na América Latina. ${ }^{5}$ Como bem aponta Beatriz Sarlo (1992), as intenções envolvidas na publicação de revistas são distintas daquelas que levam os intelectuais a publicarem livros. Enquanto estes buscam perdurar no tempo, para além de seu próprio momento de produção, os periódicos intelectuais se vinculam intrinsecamente ao presente e às "intervenções exigidas pela conjuntura." Seus objetivos não se relacionam tanto com teorizações mais gerais, mas, principalmente, com a intervenção em um debate público em torno de temas entendidos como urgentes e em relação aos quais é preciso posicionar-se. Por isso, para Sarlo, “dentre todas as modalidades de intervenção cultural” é a revista a que mais "coloca sua ênfase sobre o público, imaginado como espaço de alinhamento e conflito", o que, posteriormente, a transforma em excepcionais "espaços de reconstrução histórica." (SARLO, 1992, p. 9; 15)

No caso específico do tema do indigenismo, seu estudo através dos periódicos intelectuais se mostra particularmente importante, tendo em vista seu caráter por definição heterogêneo. Ao longo do século XX, o indigenismo procurou legitimar-se, ao mesmo tempo, enquanto um discurso teórico - de cunho científico e geralmente antropológico - e como uma prática política. Acompanhar as reflexões em torno desse fenômeno desenvolvidas por um dos mais destacados indigenistas do continente americano ao longo de décadas nos permite identificar importantes questões envolvidas nos debates político-intelectuais que perpassaram o tema no período abordado. Na década de 1920, através dos editoriais de Manuel Gamio em Ethnos, nos acercamos às questões envolvidas na estruturação institucional de uma política indigenista oficial no México pós-revolucionário; durante as décadas de 1940 e 1950, através dos editoriais de

\footnotetext{
${ }^{5}$ Entre essas obras, destacam-se as coletâneas organizadas por: COSTA; MAÍZ, 2018; CRESPO, 2010;
} SOSNOWSKI, 1999. 
Gamio em América Indígena, às problemáticas e discussões que perpassaram a tentativa de se forjar uma plataforma indigenista de alcance continental.

\section{Manuel Gamio, a Dirección de Antropología e a revista Ethnos}

Nascido em uma família de classe média urbana na Cidade do México, Manuel Gamio iniciou sua formação acadêmica nas Ciências Sociais em 1906, fazendo cursos de Arqueologia, Etnologia e Antropologia ofertados pelo Museu Nacional. ${ }^{6}$ Posteriormente, trabalhou na mesma instituição como auxiliar interino nos estudos de História e foi responsável por conduzir, em 1908, a exploração arqueológica em Chalchihuites, Zacatecas. A partir deste trabalho, com a mediação da antropóloga e arqueóloga americana Zelia Nutall, Gamio conseguiu uma bolsa de pós-graduação na Universidade de Columbia, em Nova York, sob orientação do antropólogo alemão naturalizado estadunidense, Franz Boas. Na universidade, participou, a convite do professor Marshall H. Saville, de uma expedição para o Equador organizada pelo Museu do Índio Americano, em 1910. (MATOS MOCTEZUMA, 1972, p. 9)

Ao concluir seus estudos em Columbia, em 1911, Gamio retornou ao México e matriculou-se na recém-fundada Escuela Internacional de Arqueología y Etnologías Americanas, então dirigida por Eduard Seler e, posteriormente, por Franz Boas. Inaugurada nos momentos finais do Porfiriato, a instituição contava com as parcerias e o patrocínio das Universidades de Harvard, Pensilvânia e Columbia, além do apoio dos governos do México, França e Prússia. Ao longo dos anos, a escola constituiu-se como um importante centro de investigações, que impactou profundamente a formação do antropólogo e arqueólogo e contribuiu para o desenvolvimento dos estágios iniciais do indigenismo mexicano. (KOURÍ, 2010, p. 423)

As conexões com Boas e com o culturalismo são evidentemente significativas na formação de Gamio. Uma das figuras mais importantes da Antropologia da época, Franz

\footnotetext{
${ }^{6}$ Estamos nos referindo ao antigo Museu Nacional de Arqueologia, História e Etnologia fundado por Guadalupe Victoria em 1825.
} 
Boas foi precursor do relativismo cultural, perspectiva teórica e metodológica que contestava o evolucionismo e a hierarquização das manifestações culturais. Crítico das noções que promoviam ideias de superioridade racial, defendia a compreensão dos grupos étnicos dentro de seus próprios contextos. (BONFIL BATALLA, 1987, p.170) Para Boas, era fundamental não abstrair, da análise antropológica, variáveis como o meio ambiente e especialmente as condições sociais em viviam as populações, e não as supostas características "raciais". (CASTRO, 2005, p.19)

Segundo Guillermo Castillo Ramírez (2012), Gamio recebeu de Franz Boas o legado da valorização das particularidades culturais dos grupos humanos, a negação da existência de inferioridades raciais inatas e a crítica à perspectiva mecânica e acumulativa do progresso. (CASTILLO RAMÍREZ, 2012, p. 32) Em diversas oportunidades, Gamio elogiou os "métodos originais" do professor, reconhecendo-se como seu "discípulo e amigo" e fazendo questão de salientar suas contribuições científicas para a Antropologia. Em Los prejuicios en Arqueología y Etnología, ${ }^{8}$ de 1913, destacou a importância da obra The Mind of Primitive Man (1911):

\begin{abstract}
En el que el ilustre profesor condena los prejuicios con que frecuentemente es considerada la aptitud intelectual de las diversas agrupaciones humanas y comprueba que no existe la pretendida inferioridad innata que se atribuye a algunos de esos grupos en relación con otros, sino que es producida por causas de orden histórico, biológico, geográfico, etc., etc., es decir: causas de educación y medio, que al variar hacen que desparezca aquella inferioridad. La generalización de tan lógicas ideas es indispensable entre nosotros, que constituimos un conjunto de agregados sociales étnicamente heterogéneos, cuyo progreso no es sincrónico y no se desarrolla en sendas paralelas, sino divergentes. (GAMIO, 1913, p. 43)
\end{abstract}

De maneira similar, Gamio afirmava que todos os grupos humanos possuíam as mesmas capacidades intelectuais, desde que estivessem em igualdade de condições. (GAMIO, 1916, p. 39) Utilizando os aportes teóricos de Boas, fez crítica aos estudos

\footnotetext{
${ }^{7}$ Palavras pronunciadas em memória de Franz Boas. Consultar: Gamio, Manuel. Franz Boas en México. Boletín Bibliográfico de Antropología Americana (1937-1948). Vol. 6, No. 1/3, janeiro a dezembro, 1942, p. $35-42$.

${ }^{8} \mathrm{O}$ texto posteriormente foi adaptado e incluído em Forjando Patria com o título "Los prejuicios sobre la raza indígena y su história".
} 
produzidos sobre os indígenas no México que, segundo ele, eram carregados de preconceitos e garantiu que "el indio tiene iguales aptitudes para el progreso que el blanco; no es ni superior ni inferior a él." (GAMIO, 1913, p. 44) Gamio também condenou a escassez de estudos que tomassem estes grupos como objeto e que procurassem "promover o seu desenvolvimento". Assim, atribuiu à Antropologia o papel de levar a cabo este projeto.

Ao longo dos anos, Gamio procurou adaptar a ciência acadêmica à prática, estimulando sua reorientação para o conhecimento e a compreensão de características sociais, culturais e econômicas dos grupos que compunham o país, além de defender sua aplicação à práxis social de transformação da população. ${ }^{9}$ Concebendo-a como uma ciência política com papel estratégico em auxiliar o Estado, sua finalidade seria a construção da ideia de nacionalidade. (BÁEZ JORGE, 1993, p. 20; AGUIRRE BELTRÁN, 1990, p. 275) Sobre essa perspectiva, afirmou em Forjando Patria (1916):

La Antropología en su verdadero, amplio concepto, debe ser el conocimiento básico para el desempeño del buen gobierno, ya que por medio de ella se conoce a la población que es materia prima con que se gobierna y para quien se gobierna. Por medio de la Antropología se caracterizan la naturaleza abstracta y la física de los hombres y de los pueblos y se deducen los medios apropiados para facilitarles un desarrollo evolutivo normal. (GAMIO, 1916, p. 23)

Ao analisar a situação do México, comparando-a a países como a Alemanha, o Japão e a França, que, em sua visão, "gozan de nacionalidad definida e integrada" (1916, p. 11), Gamio concluiu que a diversidade étnica, linguística e cultural que caracterizava seu país seria um entrave para a construção da nação. A identificação da exclusão histórica dos grupos indígenas no corpo jurídico mexicano resultou em sua ênfase na relação de proximidade entre a legislação e o desenvolvimento do país. Dessa

\footnotetext{
9 A perspectiva assumida por Gamio em sua atuação pode ser vinculada à chamada Antropologia aplicada, com a qual, possivelmente, ele teve contato nos Estados Unidos, onde a aplicação da ciência antropológica para a organização de políticas públicas já era praticada desde fins do século XIX. Ver a respeito: RYLKO-BAUER; SINGER; VAN WILLIGEN, 2006.
} 
maneira, passou a defender a criação de leis como produto de um estudo antropológico e condição básica para um bom governo.

A partir da constatação da heterogeneidade da população mexicana, Gamio passou a defender a mestiçagem como algo positivo, reforçando a sua viabilidade em torno da figura do indígena. Acabou distanciando-se, em certa medida, da perspectiva racialista ${ }^{10}$ que dominou o período anterior, que via no índio um elemento estranho que impediria o progresso do país. Através dessa nova abordagem, foram reconhecidas nesses povos características que contribuiriam para a constituição da cultura nacional. A formação da nacionalidade se daria, assim, a partir da incorporação e fusão dos grupos dispersos, "tendiendo, en fin, a hacer coherente y homogénea la raza nacional, unificado el idioma y convergente la cultura." (GAMIO, 1916, p. 14) O indigenismo proposto por Gamio reforçava, portanto, o ideal de um mexicano mestiço como símbolo da identidade nacional. Nesse sentido, a viabilidade de construção da nação se daria dentro de uma perspectiva de incorporação desses povos.

De fato, Gamio diferenciou-se de muitos intelectuais que pensavam as questões raciais no período, na medida em que procurou romper com explicações que associavam raça e cultura, adotando um método de análise com uma abordagem sociocultural. No entanto, é importante salientar que suas propostas assumiram frequentemente um caráter ambivalente e seletivo, ao enaltecerem o relativismo cultural, ao mesmo tempo em que reforçavam a necessidade de homogeneização dos povos que compunham o país. Além disso, é importante salientar que a centralidade que os indígenas ocuparam em suas reflexões e a defesa de uma aplicação para a Antropologia estiveram, quase sempre, atrelados à questão nacional e ao interesse de incorporá-los a esse projeto.

Reconhecendo o papel do Estado mexicano, da Antropologia e das instituições científicas no processo de reorganização do ordenamento social, Gamio integrou os

\footnotetext{
${ }^{10} \mathrm{O}$ racialismo é compreendido aqui a partir da definição e da distinção terminológicas do termo racismo, feitas por Tzvetan Todorov. Enquanto o primeiro conceito diz respeito a uma doutrina relacionada às raças humanas, o último refere-se a um comportamento ou prática excludente, direcionado a pessoas ou grupos com características físicas diferentes. (TODOROV, 1993, p. 107)
} 
principais órgãos e projetos indigenistas no México e procurou ocupar cargos na administração pública, conquistando espaço durante os governos de Venustiano Carranza (1917-1920) e Álvaro Obregón (1920-1924). Dessa maneira, contribuiu para construir as bases teóricas e institucionais do indigenismo mexicano, firmando-se como um de seus principais ideólogos.

Entre dezembro de 1915 e janeiro de 1916, ao participar como delegado da comissão mexicana no II Congresso Científico Panamericano, em Washington, propôs a criação de um "Instituto Antropológico Central” no México, que seria responsável por estudar integralmente grupos que compunham o país, seguindo critérios científicos. A partir da sugestão, a Antropologia e o indigenismo ganharam espaço institucional durante o governo de Venustiano Carranza, com a fundação da Dirección de Estudios Arqueológicos e Etnográficos, em 1917. Vinculada à Secretaría de Agricultura y Fomento, a instituição tinha como objetivos a aquisição de conhecimentos referentes ao território e à população mexicana, "especialmente la de origen indígena", a investigação de meios adequados para estimular o desenvolvimento econômico, físico e intelectual destes grupos, além da preparação para a fusão cultural, linguística e o equilíbrio econômico, já que "solo así formarán uma nacionalidade coerente y definida y uma verdadeira patria". ${ }^{11}$ Em 15 de agosto de 1919, a instituição teve seu nome alterado para Dirección de Antropología, por sugestão do então presidente, que constatou inadequação do nome anterior aos objetivos do órgão, ligados diretamente ao estudo da população. (DEL VAL; ZOLLA, 2014, p. 113)

Gamio dirigiu a Dirección durante toda sua existência, de 1917 a 1924, definindo como ponto central de sua atuação o estudo integral dos grupos que compunham o país, através de análise quantitativa (estatística), qualitativa (tipo físico, idioma, civilização e cultura), cronológica (períodos pré-colonial, colonial e contemporâneo) e de condições ambientais (fisiobiologia regional). (GAMIO, 1916, p.

\footnotetext{
${ }^{11}$ A respeito consultar: Programa de la Dirección de Estudios Arqueológicos y Etnográficos, Secretaria de Agricultura y Fomento. Oficina Impresora de la Secretaria de Hacienda, Departamento de Fomento, México, 1918.
} 
28) Para investigar os elementos básicos sobre a população e o território, dividiu o país em onze zonas representativas, que deveriam ser pesquisadas através destes aspectos. (LEÓN-PORTILLA, 1986, p. 24) Como resultado dos estudos da primeira região, foi publicada La población del Valle de Teotihuacán, em 1922, investigação multidisciplinar composta por dados culturais, demográficos, geográficos e geológicos da região. A pesquisa recebeu diversos prêmios e lhe rendeu o doutorado em Filosofia pela Universidade de Columbia. (MATOS MOCTEZUMA, 1972, p.14)

Além da atuação prática, um dos desdobramentos mais significativos de sua atuação na Dirección foi a idealização de Ethnos: Revista Mensual para la vulgarización de estúdios antropológicos sobre México y Centro América, em 1920. Apesar de sua importância como o primeiro periódico dedicado à Antropologia e ao indigenismo da América Latina (GONZÁLEZ GAMIO, 2017, p. 20), nota-se uma escassez de estudos mais aprofundados sobre a revista. A grande maioria dos trabalhos sobre Gamio dedica-se à análise de Forjando Patria e de seu papel como indigenista, fazendo breves menções à Ethnos ou até mesmo ignorando sua atuação editorial.

Compreendendo as publicações periódicas como importantes fontes históricas e como espaços de intervenção que procuram atuar em seu contexto de produção (SARLO, 1992), acreditamos que a análise dos editoriais escritos por Gamio na Ethnos têm muito a nos dizer sobre seu papel como indigenista e sobre sua importância na estruturação de políticas e projetos voltados às populações indígenas no México e América Latina. Desse modo, apresentaremos brevemente os elementos da materialidade da revista e analisaremos seus editoriais, dando ênfase àqueles que abordam mais diretamente a questão indígena.

Constituindo-se como uma das revistas especializadas em Ciências Sociais mais importantes do México, Ethnos foi concebida por Gamio como um veículo de difusão das investigações feitas pela Dirección. No entanto, por falta de apoio econômico estatal, acabou sendo publicada por iniciativa própria (GONZÁLEZ GAMIO, 2003, p. 
84), o que não impediu que, ao longo de suas edições, trabalhos realizados pela instituição fossem frequentemente divulgados.

Segundo seu programa, a revista seria responsável por disseminar estudos científicos feitos tendo como referência a população mexicana, contribuindo para "hacer saber cuán mínima e insignificante es la proporción de grupos sociales mexicanos que son científicamente conocidos o siquiera superficialmente apreciados." Buscava-se, assim, despertar o interesse público e fazer com que setores governamentais, instituições sociais e associações científicas tomassem conhecimento da realidade social e se mobilizarem para "la redención positiva de los grupos". (Ethnos, programa, Tomo I, no 2, maio de 1920, s./p.)

Os artigos eram escritos por pesquisadores mexicanos e estrangeiros, relacionando-se principalmente à História, Arqueologia, Direito, Sociologia, Antropologia e Etnologia. Além da versão em espanhol, muitos contavam com um resumo em inglês. A maioria das edições apresentavam ilustrações, gravuras e fotografias, que representavam grupos étnicos, regiões, trajes, objetos de arte, estruturas arquitetônicas e explorações arqueológicas. A revista tinha circulação nos Estados Unidos, Canadá, Cuba, além do próprio México, e poderia ser assinada semestralmente ou comprada em volumes avulsos.

Como já mencionado, Ethnos foi publicada entre 1920 e 1925 e foi dividida por seus editores em três épocas. Manuel Gamio atuou como diretor da revista durante as duas primeiras épocas (1920 a 1923) e o sociólogo e jurista Lúcio Mendieta y Núñez assumiu a direção na terceira época, publicada somente em 1925.

Ethnos teve uma periodicidade irregular, sofrendo interrupções ao longo de alguns meses, causadas por dificuldades financeiras e de conciliação dos trabalhos da equipe. Na maioria das edições, o jornalista e linguista Pablo González Casanova e o também jornalista e pesquisador Ignacio B. del Castillo atuaram como secretários de redação e o professor e pesquisador Paul Siliceo Pauer como gerente. Alguns 
colaboradores, incluindo os citados acima, já eram parceiros de Gamio desde as investigações feitas no Valle de Teotihuacán.

Sob direção de Manuel Gamio, a primeira época da revista contou com o maior número de publicações: doze números com, em média, trinta páginas cada. Os cinco primeiros volumes foram publicados mensalmente, mas as edições seis e sete (de setembro e outubro de 1920) e oito a doze (de novembro de 1920 a março de 1921) tiveram suas edições agrupadas, mudando o padrão mensal anterior.

Durante a segunda época, houve a alteração em seu nome e peridiocidade. Passando a se chamar Ethnos: Revista dedicada al estudio y mejoría de la población indígena de México, o periódico adotou um formato trimestral e mais extenso, com cem páginas em média. O editorial de sua $1^{\mathrm{a}}$ edição, que correspondia a novembro de 1922 a janeiro de 1923, foi dedicado a explicar as modificações, atribuídas às dificuldades econômicas e a possibilidade de publicação de estudos mais completos.

A terceira época foi marcada pela saída de Manuel Gamio da direção da revista. Em 1924, a convite do então presidente Plutarco Elías Calles, o antropólogo e arqueólogo passou a ocupar o cargo de subsecretário de Educação Pública. No entanto, em junho do ano seguinte, renunciou a suas funções estatais após denunciar irregularidades na Secretaria. (MATOS MOCTEZUMA, 1972, p. 16)

Lucio Mendieta y Núnez foi quem assumiu o posto de diretor na última época de Ethnos. Portanto, ele foi possivelmente o autor dos editoriais da revista nesse período, apesar de alguns pesquisadores, como o arqueólogo Eduardo Matos Moctezuma (1972, p. 16), afirmarem que Gamio escreveu todos os editoriais. Como já mencionamos, Ethnos não tem sido tomada como objeto de investigação histórica, mas apenas mencionada em trabalhos que analisam o pensamento de Gamio principalmente por meio de Forjando patria, o que tem levado a generalizações e informações pouco precisas em relação à revista. Nossa posição de não identificá-lo como o autor dos últimos editoriais de Ethnos se baseia na evidência de que ele não foi o diretor da 
publicação em seu último ano. Portanto, nossa análise vai se deter nos editoriais da primeira e segunda épocas da revista.

Antes de tudo, é interessante notar que os editoriais escritos por Gamio na Ethnos são bastante voltados às questões nacionais. Aparece de maneira recorrente o discurso de urgência em se desenvolver investigações que compreendessem os grupos sociais mexicanos, principalmente os indígenas, e a necessidade de um Estado que tomasse conhecimento sobre esses aspectos. O estudo integral da população é tido nesses textos como o passo inicial para identificar "carências" e traçar possibilidades de ação.

Em "Los cambios de gobierno en México", editorial publicado em maio de 1920, como o próprio título sugere, Gamio reflete sobre as mudanças governamentais no país, causadas pelo fim do governo de Venustiano Carranza, e defende a promoção de conhecimentos científicos sobre as condições e características da população para a condução de um bom governo. Sua análise ressalta a constante instabilidade política mexicana, comparando-a à realidade de países como a Suíça, a Rússia e o Japão que, segundo ele, apresentavam um "avanzado grado evolutivo", onde a política seria resultado dos "esfuerzos colectivos y de concienzudas observaciones, investigaciones y experiencias sociales" e "del modo de sentir y obrar de la población". De maneira oposta, no México, governo e população seriam "antagónicos, porque aquél nunca ha conocido las verdaderas aspiraciones de esta". A partir da reflexão, Gamio conclui que seria impossível "estudiar y resolver a golpe los árduos y abstrusos problemas sociales" para depois estabelecer um sistema político adequado. Portanto, através do editorial, sugere que o governo, assim que estabelecido, estimule "la investigación de nuestros grandes problemas sociales, étnicos, culturales y económicos." (Ethnos, editorial, Tomo I, no 2 , maio de 1920, s./p.)

Nota-se aqui como Gamio, enquanto diretor de Ethnos e responsável pela Dirección de Antropología, atuou politicamente para reafirmar suas propostas para a nação, além de defender a importância da própria revista que, em grande medida, se 
entrelaçava a esse projeto nacional. Vale lembrar que essa posição se deu em um conturbado contexto de transição política, marcado pelo desgaste e fim do governo de Carranza, assassinado em Tlaxcalantongo, em de maio de 1920, e pelo início do mandato interino de Adolfo de la Huerta. (AGUILAR CAMÍN; MEYER, 2000, p.95),

De maneira semelhante, em "El conocimiento de la población mexicana y el problema indígena", um dos editoriais mais longos da revista, publicado em julho de 1920, Gamio reforçou a urgência em dar atenção a este "problema", produzindo conhecimentos sobre os grupos indígenas que configuravam a maioria da população mexicana. A argumentação tomava como referência o Congresso de Raças, realizado em Londres em 1911, que havia deixado "asentado que resolver satisfactoriamente la cuestión de heterogeneidad de razas y civilizaciones es tarea de honda transcedencia universal y nacional". Além disso, reiterou estudos estrangeiros que indicavam que o México deveria "preocuparse urgentemente en estudiar los medios de incorporar a la vida nacional, las masas aborígenes". A parte final do editorial é reservada a reafirmar a importância da Dirección de Antropología, instituição na qual era diretor, divulgando os estudos realizados no Valle de Teotihuacán e apontando perspectivas de que "el gobierno tomará en consideración las indicaciones que en ella se hacen tendentes a corregir las deficiencias notadas." (Ethnos, editorial, Tomo I, nº4, julho de 1920, p.75-85)

Em "El empirismo legislativo y el criterio presidencial ante el problema indígena", publicado na edição de setembro e outubro de 1920, Gamio elogia o novo presidente, Álvaro Obregón, por sua coragem em expor suas ideias sobre os problemas sociais do país. O texto é particularmente interessante, já que relaciona os interesses do novo governo aos da revista, que incluíam a "repartición de terras; redención física e intelectual de la gran masa indígena; reconsideración de leyes exóticas e inadecuadas." (Ethnos, editorial, Tomo I, n's 6 e 7, set. e out. de 1920, p.135-136)

É importante compreender a revista como um plano de ação política que desempenhou um importante papel em pautar os debates indigenistas no país. O 
alinhamento dos propósitos da Ethnos às concepções teóricas de Gamio e ao que este compreendia como as estratégias necessárias para a construção da nacionalidade mexicana são bastante evidentes. Além da práxis editorial, o intelectual utilizou as páginas da revista para apresentar suas análises sobre a realidade social mexicana, inserindo-se nos debates nacionais e constituindo-se como um dos ideólogos mais importantes do indigenismo. O periódico desempenharia, para Gamio, o importante papel no avanço da produção e divulgação do conhecimento científico, para que este pudesse orientar a ação governamental na elaboração de projetos para a nação.

Durante a segunda época de Ethnos, com as mudanças em sua periodicidade e nome, nota-se um estreitamento desses objetivos. $O$ programa de divulgação antropológica da primeira época foi mantido, mas houve uma maior ênfase no "problema indígena", com estudos analíticos dos antecedentes pré-hispânicos, coloniais e atuais "de la raza indígena", buscando "su mejoría física, intelectual y económica", para "la fusión racial de los elementos heterogéneos que hoy constituyen a la población mexicana". De acordo com Gamio, "sin esto no puede existir la patria, ni la nacionalidade.” (Ethnos, editorial, 2 época, Tomo I, nº 1, Nov. 1922 a Jan. 1923, p.1-2)

Na publicação seguinte, o editorial "Nacionalismo e Internacionalismo" traz uma reflexão sobre os "movimentos de renovação social", que tomavam o mundo e a inevitabilidade da "evolução". Gamio, no entanto, firma posição contrária ao internacionalismo, entendido aqui como a "abolición de nacionalidades y de exclusivistas fronteras geográficas”. Segundo o antropólogo e arqueólogo, apesar de tender ao internacionalismo das "corrientes del pensamiento reinante en los países avanzados", era preciso ser nacionalista renunciando aos afãs modernistas pela "civilización indígena retrasada en varios siglos". A posição contrária se justificaria pelo fato de que, em sua concepção, o México, assim como outros países da América Latina, ainda não seria uma nação. De acordo com Gamio, a coexistência de "individuos de alto tipo cultural" com aqueles que "viven la existencia de hace cuatro siglos y algunos hasta la paleolítica", casos do "Brasil, México, Colombia, Ecuador, Perú, etc", 
teria como resultado a "preponderancia da alta civilización", aqui entendida como a modernidade ocidental, "y la decadencia y aún pronta desaparición de los retrasados". Era necessário, portanto, evitar que isso acontecesse no México e em países análogos. $\mathrm{O}$ internacionalismo seria viável, mas apenas no futuro. Antes disso, era preciso construir a nação promovendo "el mestizaje, a fin de que la raza sea homogénea." (Ethnos, editorial, $2^{\circ}$ época, Tomo I, $\mathrm{n}^{\circ} 2$, fev. a abril de 1923, s./p.)

Através dos editoriais, observamos que a atuação de Gamio na Ethnos foi bastante focada em questões nacionais, apresentando problematizações sobre o período e projetos para o futuro do país. Fica evidente seu papel no redirecionamento das Ciências Sociais, especialmente a Antropologia, para a compreensão de características e das condições de vida dos grupos indígenas e resolução dos "problemas nacionais", convertendo-as em ferramentas para consolidação do Estado e estreitando seus laços com setores governamentais.

O indigenismo apresentado pelo antropólogo e arqueólogo na Ethnos centrou-se em recuperar a figura autóctone como elemento sobre o qual seria possível construir a identidade nacional mexicana. Dessa forma, sua incorporação foi defendida nos editoriais da revista como o único meio capaz de promover unidade à pátria e sustentar as bases de um novo regime. No entanto, apesar de negar a existência de atributos ou superioridades intelectuais ou raciais inatas às culturas, é possível identificar nos textos de Gamio elementos de uma visão evolucionista e comparativa. Ao considerar que determinados grupos se encontravam em graus distintos de evolução, Gamio qualificou o nível cultural desses povos. Esse tipo de concepção se dava a partir da organização de uma hierarquia evolutiva criada através da quantificação e classificação utilitária de características tidas como eficientes, deficientes ou prejudiciais. (AGUIRRE BELTRÁN, 1990, p. 278)

Além disso, o uso reiterado de noções como "problema indígena" e de ideias dicotômicas e comparativas de progresso e atraso ou cultura ocidental versus cultura aborígene, evidencia o que Guillermo Castillo Ramírez chamou de “concepção 
catalogadora e evolucionista" em Gamio. Ao fazer juízos de valor classificando esses grupos com elementos "positivos" e "negativos", de acordo com padrões socioculturais ocidentais, ele afirmava que os indígenas estavam atrasados (CASTILLO RAMÍREZ, 2012, p. 39). Para Emilio Kourí, era evidente que, para Gamio, havia culturas em diferentes estágios evolutivos, mas essas diferenças não eram fruto de uma hierarquia natural. Portanto, o "problema dos índios" não seria uma inferioridade racial inata, mas um atraso evolutivo de causas históricas, que poderia ser remediado incrementando suas condições de vida. (KOURÍ, 2010, p. 426-427) Gamio sustentou, dessa forma, a existência de uma "distância evolutiva" entre as culturas, defendendo o estímulo de "melhorias" para a superação das diferenças, além de destacar o papel dos mais "civilizados" em conduzir os demais ao "progresso".

Segundo Bonfil Batalla, o pensamento de Gamio foi importante em matizar noções como a inferioridade racial indígena ou a negação de qualquer valor nessas culturas, mas frequentemente admitia um maior desenvolvimento da cultura ocidental. Suas propostas indigenistas diferenciavam-se por prever uma etapa de transição na incorporação, na qual, durante certo tempo, haveria espaço para as especificidades dos variados grupos, o que facilitaria e tornaria menos conflituoso este processo. (BONFIL BATALLA, 1987, p. 170-171) Ao fim e ao cabo, o projeto indigenista de Gamio encobria uma prática de dominação, não deixando de propor a eliminação das especificidades destes grupos, negando sua etnicidade.

\section{Manuel Gamio, o Instituto Indigenista Interamericano e a revista América Indígena}

Manuel Gamio chegou à direção do Instituto Indigenista Interamericano (I.I.I.) em 1942, após a morte de seu idealizador e primeiro diretor, o também mexicano Moisés Sáenz Garza, que era educador de formação. Até então, Gamio não fazia parte do órgão indigenista continental nem havia participado de sua criação - que ocorreu a partir do Primeiro Congresso Indigenista Interamericano, realizado na cidade mexicana 
de Pátzcuaro em 1940 - visto que o indigenismo proposto por Sáenz como plataforma para o I.I.I. era bastante distinto daquele defendido por Gamio.

Durante boa parte de sua trajetória indigenista, Moisés Sáenz havia partilhado do paradigma da "incorporação indígena", que era defendido não apenas por Manuel Gamio, mas por boa parte da intelectualidade indigenista do período. Sua proposta era, basicamente, assimilar os indígenas à "civilização moderna", o que, para muitos, se daria a partir de um processo de mestiçagem cultural, por meio do qual os povos indígenas se apropriariam de caracteres culturais ocidentais e se afastariam de elementos de suas culturas que "repugna[ban] a la cultura ocidental". (AGUIRRE BELTRÁN, 1990, p. 156)

No entanto, em fins dos anos 30, Sáenz empreendeu uma mudança significativa em sua perspectiva indigenista, passando a defender o que ele chamou de “integracionismo", em franca contraposição ao modelo da incorporação. Em sua última obra, México íntegro, publicada em 1939, Sáenz declarou explicitamente sua mudança de perspectiva e explicou, nos seguintes termos, sua proposta integracionista como sendo uma teoria social mais adequada:

\begin{abstract}
Un juicio definitivo que contemple una adecuada teoría social tendría que ser contrario a la fórmula de la 'incorporación'. Se la rechazaría por simplista y por descansar en un concepto mecanista [sic] del proceso. Postula, en efecto, la existencia de dos entidades, la mexicana y la india, [...] y supone una especie de amalgama en la que el conglomerado mexicano absorbería las unidades indígenas. Cuando se empezó a usar el término se decía petulantemente "incorporación del indio a la civilización." [...] [Pero] el proceso social no es $[\ldots]$ un proceso mecánico ni puede tener analogía con las combinaciones químicas. (SÁENZ, 2007 [1939], p. 145)
\end{abstract}

A crítica de Sáenz à tese da incorporação a partir da referência à analogia com as misturas químicas era uma alusão indireta, mas bastante evidente, à lógica de Gamio de "forja" da pátria, inspirada na forja de metais, como um processo de mestiçagem cultural que levaria à homogeneidade nacional tão sonhada pelo antropólogo e arqueólogo. Ao contrário dessa visão de nação culturalmente homogênea, que era, sem dúvida, a hegemônica na época, o que Moisés Sáenz propunha como "integracionismo" 
era a ideia de um Estado-nação culturalmente plural, embora suficientemente integrado. Ele assim o explicou: "convencido dos males da uniformidade [...], me declaro a favor do pluralismo cultural, integrado pelo conceito de uma Pátria grande e ligado por um sistema econômico justo”. (SÁENZ, 2007 [1939], p. 33)

Essa visão de Saénz estava bastante próxima do que chamamos atualmente de multiculturalismo, como tem sido destacado por estudos recentes sobre sua última obra. 12 Além disso, sua proposta indigenista se mostrava impregnada da ideia de justiça social, o que se traduzia em uma forte defesa da reforma agrária e da posse comunal da terra pelos indígenas. Não por acaso, o grupo encabeçado por Sáenz recebeu apoio político do governo de Lázaro Cárdenas, já em seus últimos anos, para organizar o Primeiro Congresso Indigenista Interamericano, cuja intenção principal era criar uma instituição indigenista de alcance continental. O evento contou com a participação de representantes de praticamente todos os países do continente (apenas Paraguai e Canadá não enviaram representantes oficiais ao Congresso) e aprovou a criação de um Instituto Indigenista Interamericano, que deveria ser organizado por um Comitê Executivo, que também foi definido no evento e contava com representantes de vários países do continente: os Estados Unidos, representado por John Collier, que era um amigo pessoal de Saénz e à época ocupava o cargo de comissário de Assuntos Indígenas de seu país, tendo tido uma atuação fundamental para garantir o apoio do governo estadunidense ao projeto de criação de uma instituição indigenista continental; ${ }^{13}$ a Guatemala, representada por David Vela; o Peru por Uriel García; a Bolívia por Antonio Díaz Villamil; o Brasil por Roquette Pinto; e o México por Luis Chávez Orozco, além do próprio Moisés Sáenz, como diretor provisório da nova instituição. (GIRAUDO, 2011, p. 82)

Uma das primeiras ações levadas a cabo pelo I.I.I., ainda em fase de organização, foi a criação de uma revista, América Indígena: órgano trimestral de

\footnotetext{
${ }^{12}$ Consultar a respeito: AGUILAR RIVERA, 2007.

${ }^{13}$ Sobre o apoio financeiro do governo estadunidense ao projeto do I.I.I. desde seus inícios no Congresso de Pátzcuaro e a importância da atuação de John Collier nesse contexto, consultar: GIRAUDO, 2011.
} 
Instituto Indigenista Interamericano, e também seu "suplemento", com periodicidade bimestral, o Boletín Indigenista. ${ }^{14}$ A função de América Indígena (AI), revista oficial do I.I.I., foi definida como sendo "formentar el intercambio de informaciones acerca de la vida indígena actual y la política y programas que se están desarrollando en su favor." (AI, vol. 1, n 1, oct. 1942, p. 1) Apesar de usar a genérica expressão "intercâmbio de informações", a concepção original de Sáenz para a publicação do I.I.I. era que esta fosse um veículo de divulgação de políticas públicas e estudos de caráter indigenista levados a cabo inclusive pela própria instituição, tendo sempre um caráter "normativo". Nesse sentido, destacou, em um texto que preparou para o primeiro número de AI, que as finalidades das investigações científicas desenvolvidas pelo I.I.I. "estar[ían] imbuidas de una tendencia normativa; sus búesquedas, encuestas y catastros constituirán datos y elementos de acción, acción cuya realización el Instituto promoverá entre las autoridades y organismos competentes.” (SÁENZ, 1941apud GIRAUDO, 2011, p. 38)

Mas esse texto de Moisés Sáenz não chegou a ser publicado em AI e a atuação do I.I.I. e de sua revista tampouco vieram a se concretizar como ele havia proposto. A morte inesperada de Sáenz em outubro de 1941, no mesmo momento em que se publicava o primeiro número da revista e quando o próprio I.I.I. ainda se encontrava em fase de estruturação, marcou uma mudança completa de perspectiva em relação à instituição. Quase que imediatamente após a morte de Sáenz, Manuel Gamio foi eleito pelo Comitê Executivo como o novo diretor do I.I.I.; embora a escolha de Gamio se justificasse, em certa medida, por suas credenciais acadêmicas - sendo que ele se destacava entre a maioria dos indigenistas do continente por ter um doutorado -, também é inegável a dimensão política envolvida em sua eleição.

Como mostra a historiadora Laura Giraudo (2011), que tem se dedicado ao estudo do I.I.I., a posição de Moisés Sáenz de um indigenismo político e militante já se mostrava minoritária dentro do Comitê Executivo do I.I.I. pouco antes de sua morte.

\footnotetext{
${ }^{14}$ A respeito de ambas as publicações do I.I.I., sua criação e organização nos inícios da instituição e seu papel na estruturação de uma rede intelectual indigenista de caráter transnacional em torno do Instituto, consultar: DIAS, 2018.
} 
Dessa forma, a mudança de orientação da instituição não ocorreu simplesmente devido à morte de Sáenz. Efetivamente, como aponta a autora, a ascensão de Gamio à direção do I.I.I. representou uma mudança decisiva em relação às propostas de Saénz, mas na prática definiu algo que havia ficado em discussão desde o Congresso Indigenista de Pátzcuaro, no qual os debates em torno da definição do caráter do indigenismo interamericano estiveram "ranging from the idea of a need to transform and 'improve' the lives of indigenous people to the defense of maintaining or revitalizing their customs and institutions to cultural pluralism or even political self-determination." Assim, quando Gamio tornou-se diretor do I.I.I., em março de 1942, consolidou-se "el alejamiento inexorable del indigenismo militante, político y social de Sáenz" a favor de "un indigenismo apolítico y científico defendido por Gamio." (GIRAUDO, 2012, p. 15; 2011, p. 87, 85) O antropólogo e arqueólogo mexicano ocupou a direção da instituição indigenista continental e de sua publicação oficial de 1942 até sua morte, em 1960.

Antes de adentrarmos propriamente na análise dos editoriais publicados por ele na revista AI, faremos uma breve descrição dos aspectos da materialidade da publicação, para que o leitor possa ter uma noção também dessa dimensão.

América Indígena: órgano oficial del Instituto Indigenista Interamericano era uma publicação trimestral, como o próprio título indica, e seus números saíam invariavelmente nos meses de janeiro, abril, julho e outubro. As edições da revista podiam ser compradas de forma avulsa por 1,75 pesos mexicanos ou 35 centavos de dólar ou por meio de assinatura anual, custando 10 pesos mexicanos ou 2 dólares estadunidenses, quando do seu surgimento, em 1941. Em 1960, o preço havia passado para 32 pesos mexicanos ou 4 dólares e a publicação somente era anunciada para assinatura anual, não constando mais a opção de compra avulsa.

Ao longo de todo o período analisado, cada uma das edições de AI possuía em torno de 100 páginas, compostas por um editorial seguido por diversos artigos assinados por indigenistas de todo o continente, cujos textos podiam ter tanto um caráter acadêmico quando político-ideológico. A revista abria espaço para diferentes 
posicionamentos e visões, inclusive sobre o próprio sentido atribuído ao termo indigenismo, mas sempre com a ressalva de que "el Instituto Indigenista Interamericano no es responsable por el contenido de los artículos firmados", que aparecia em suas contracapas. Os artigos publicados pela revista foram majoritariamente escritos em espanhol, mas também foram publicados vários textos em inglês e português, assinados por estadunidenses, canadenses e brasileiros.

O discurso da revista no período aqui abordado também esteve bastante perpassado pelas imagens. Inúmeras fotografias de indígenas de várias regiões das Américas foram reproduzidas na revista, além de obras de arte com temáticas indigenistas. Entre as obras de arte, destacam-se principalmente as gravuras, que aparecem em praticamente todas as edições da revista de forma anônima ou assinadas por artistas como os mexicanos Alberto Beltrán e Gustavo Savín. Em menor medida, também foram reproduzidos alguns quadros de pintores como o boliviano Cecilio Guzmán de Rojas e o mexicano Francisco Goitia. Todas as imagens foram publicadas na revista em preto e branco.

Em relação aos editoriais, que nos interessam mais diretamente neste trabalho, se apresentavam como textos curtos, de cerca de 2 páginas, publicados sempre em espanhol e inglês. Por serem textos editoriais, suas ideias podem ser tomadas como expressões da política oficial do I.I.I. e sua produção atribuída diretamente a Manuel Gamio - e não a um coletivo editorial, por exemplo - tendo em vista que o nome do diretor é geralmente o único que aparece como compondo o núcleo editorial da revista. A autoria de Gamio também é reforçada em diversos desses artigos, quando o escritor do editorial remete o leitor a textos anteriores como sendo seus e estes são assinados pelo próprio diretor do I.I.I.

Muito embora Manuel Gamio não tenha participado das gestões em torno da criação da instituição indigenista interamericana, pelos motivos que já apontamos, podemos identificar que uma dimensão continental já estava envolvida em seus projetos indigenistas pelo menos desde a década de 1910. Isso aparece claramente no Programa 
da Dirección de Estudios Arqueológicos y Etnográficos do México - que foi fundada sob a direção de Gamio -, datado de 1918, no qual, não obstante definisse a atuação de uma instituição nacional, trazia uma "proposição pan-americana" da autoria de Gamio. O documento reproduzia com tal título um discurso que o arqueólogo e antropólogo havia realizado como presidente da delegação mexicana enviada ao II Congresso Científico Pan-americano, realizado nos Estados Unidos entre 1915 e 1916.

Nesse discurso, reproduzido no documento oficial mexicano, Manuel Gamio ressaltava "la importancia capital que presenta la antropología en los países latino-americanos", onde, "desgraciadamente, en casi todos los países latinoamericanos se desconocieron y se desconocen, oficial y particularmente, la naturaleza y necesidades de las respectivas poblaciones". Afirmava, ainda, que "los estudios con criterio antropológico" eram "la única manera" adequada ao conhecimento das populações indígenas e destacava que o projeto mexicano de criação de uma Direção de Antropologia era uma ação que deveria ser seguida em todo o continente. Gamio chegou a recomendar expressamente ao Congresso Científico que indicasse aos demais Estados americanos a criação de instrumentos similares ao mexicano. (MÉXICO. Secretaría de Agricultura y Fomento, 1918, p. 12-13)

Algumas décadas depois, o antropólogo e arqueólogo mexicano encontrava-se à frente do I.I.I., cargo que lhe permitia atuar mais diretamente na promoção continental de estudos e políticas indigenistas. Os editoriais que publicou em AI, como diretor da revista, permitem observar não apenas uma busca por fomentar os trabalhos antropológicos no continente como o fato de que os projetos desse cunho, bem como as políticas públicas indigenistas realizadas no México, foram colocados como o grande modelo a ser seguido pelos demais países. Gamio escreveu diversos artigos relatando seus próprios estudos no México, sinalizando o seguinte sobre suas conclusões: "las damos a conocer a las entidades indigenistas del continente, pues quizá plasmen en realizaciones eficaces [también para sus contextos].” (AI, editorial, v. VI, n. 2, abr, 1946, p. 101) 
Além disso, as próprias mudanças institucionais mexicanas relativas à questão indígena também foram divulgadas pela revista oficial do I.I.I., como no editorial de janeiro de 1947 intitulado "Reorientación de la política indigenista mexicana." No texto, Gamio explica aos leitores sobre a extinção do Departamento Autônomo de Assuntos Indígenas pelo governo de Miguel Alemán, argumentando que tal mudança havia “causado gran sorpresa en elementos indigenistas del Continente", já que "en aparencia tal acontecimento no se compadece com el alto papel que México desempeña en el movimiento indigenista continental.” (AI, v. VII, n. 1, ene, 1947, p. 3)

$\mathrm{Na}$ realidade, o protagonismo mexicano dentro do indigenismo interamericano se delineou desde o início, em boa medida devido ao fato de que o movimento em torno da articulação da instituição indigenista continental havia se dado por iniciativa mexicana, sob a liderança de Moisés Sáenz, através da convocação do Congresso de Páztuaro, em 1940, no qual foi gestado o I.I.I. Mas a liderança do México no cenário continental em relação ao tema do indigenismo na época também era reconhecida, e em grande medida legitimada, devido aos contornos institucionais que o indigenismo ganhara no México pós-revolucionário. Para se ter uma ideia do lugar hegemônico ocupado pelo país dentro da instituição indigenista continental, basta dizer que a Cidade do México foi a sede do I.I.I. e somente mexicanos foram seus diretores desde a fundação da instituição, em 1941, até o início dos anos $70 .{ }^{15}$

Ao chegar à direção do I.I.I., uma das primeiras ações empreendidas por Manuel Gamio foi estimular as comemorações relativas ao "Dia do Índio", efeméride que havia sido criada no Congresso de Pátzcuaro. Na perspectiva do novo diretor, "muchas medidas han sido propuestas y algunas realizadas en pro del Indígena de América: mejorar la higiene y el desarrollo biológico, modernizar la técnica de producción agrícola e industrial, corregir los abusos [...] de que es víctima [...], etc."

\footnotetext{
${ }^{15}$ Durante essas três décadas, a diretoria do I.I.I. somente foi ocupada por um não mexicano por alguns meses após a morte de Moisés Sáenz, entre o fim de 1941 e o início de 1942, quando o guatemalteco Carlos Girón Cerna, que era o secretário do Comitê Executivo da instituição, assumiu interinamente sua direção.
} 
Porém, continuou ele, "poco se propone y menos se hace respecto a los esparcimientos y diversiones de que debe gozar para tener una existencia completa." Segundo Gamio, era necessário levar "diversões" aos indígenas, visto que estes, ao contrário do "homem da cidade", não tinham opções de lazer e, por isso, "se entrega[ba]n a el alcohol, primero enemigo de la población indígena." Gamio propunha que principalmente o teatro fosse usado para atrair e divertir os indígenas. (AI, editorial, v. III, n. 1, ene, 1943, p. 3-4)

Essas ideias e propostas de Manuel Gamio foram expressas em sua primeira comemoração oficial do Dia do Índio como diretor do I.I.I. e representavam uma visão de indigenismo absolutamente contrária àquela que havia dado o sentido inicial à efeméride. Ela havia sido criada durante o Primeiro Congresso Indigenista de Pátzcuaro, em 1940, por iniciativa dos próprios indígenas que, juntamente com os indigenistas, representaram alguns dos países do continente no evento. O México, como país sede do Congresso, contou com a representação de 32 "delegados indígenas"; Estados Unidos com 14, Chile com 2 e Panamá com 1. (GIRAUDO, 2017, p. 83) A Ata Final do encontro explica que os indígenas propuseram a comemoração como "ocasión de encontrar el espíritu de su raza en una misma fecha cada año", destacando que o Congreso de Pátzcuaro havia sido o momento em que "por primera vez" se reuniam representantes indígenas de diversos países. (I.I.I., 1940 apud GIRAUDO, 2017, p. 83) A Ata estabelecia que a comemoração do "Día Americano del Indio" deveria ocorrer anualmente na data de 19 de abril, por ser "la fecha en que por primera vez se reunieron los Delegados Indígenas al Primer Congreso Indigenista Interamericano.” O mesmo documento também apresentava algumas "recomendações" aos países do continente ali reunidos a respeito das comemorações da data: "que los gobiernos de los países Americanos establezcan el 'Día del Indio' dedicado a estudiar en todas las Escuelas y Universidades, con criterio realista, el problema del indio actual.” I.I.I., 1940 apud GIRAUDO, 2017, p. 83) 
Portanto, no documento oficial do Congresso, a questão indígena é explicitamente apresentada como um "problema", que deveria ser estudado de forma "realista". Não podemos perder de vista que o pano de fundo sobre o qual tal proposição se colocava era a luta por reforma agrária e pela manutenção das terras comunais indígenas, elemento central do indigenismo do Congresso de Pátzcuaro, patrocinado pelo governo Cárdenas e dirigido por Moisés Sáenz. Para o educador mexicano, a questão indígena em seu sentido mais amplo e em toda a "Indoamérica" estava intrinsecamente relacionada com o problema da terra. Em suas próprias palavras: "el indio es una criatura del suelo [...], su condición misma [de indígena] depende de la conservación de su liga con el suelo: rompámosla y destruiremos al indio." (SÁENZ, 1933, p. 167) Essa relação intrínseca, social e cultural, que Sáenz identificava dos indígenas para com a terra, não era pensada em termos genéricos de acesso a um pedaço de terra, mas passava pela posse comunal como elemento primordial para a viabilização das próprias culturas indígenas.

Nesse sentido, a proposta de Manuel Gamio de que o Dia do Índio deveria ser celebrado como um momento de "esparcimientos y diversiones" torna-se extremamente reveladora da nova configuração do indigenismo interamericano orquestrada pelo antropólogo e arqueólogo a partir da direção do I.I.I. Nenhuma referência ao "problema indígena", muito menos à questão da terra, pode ser vislumbrada no sentido que Gamio procurou atribuir à efeméride. Aliás, se há um tema que chama a atenção precisamente por sua ausência nos editoriais de AI durante a gestão de Gamio é propriamente a questão agrária. E chama muito a atenção o fato de que o novo diretor do I.I.I., no início de sua gestão e da própria instituição indigenista, ao contrário de destacar como uma meta propor e desenvolver ações em defesa dos interesses das populações indígenas buscasse, muito mais, ressaltar que muitas medidas já haviam sido propostas e algumas delas já realizadas para a melhora social dos indígenas, devendo-se, então, facilitar-lhes os "esparcimientos y diversiones." 
É inegável que a experiência indigenista do mexicano o remetia primeiramente a seu próprio país, onde uma preocupação pela questão indígena já se havia institucionalizado e, sobretudo, o processo de reforma agrária, decorrente da Revolução e bastante impulsionado durante o cardenismo, de fato levavam a uma melhoria da condição social de muitos indígenas. No entanto, se nem mesmo no México, onde a participação massiva dos indígenas no movimento revolucionário havia desencadeado tal processo ele podia ser considerado como terminado, menos ainda pensando-se em termos continentais. Entre as medidas que Gamio destacou como já sugeridas e em partes realizadas para melhorar a condição indígena, elencou, como primeiro tópico, "mejorar la higiene y el desarrollo biológico." Isso é um elemento muito revelador sobre sua visão indigenista.

Ao frisar a higiene e o desenvolvimento propriamente "biológico", as expressões de Gamio nos remetem a antigos conceitos (como o de raça) e ao paradigma evolucionista, que ainda tinham muita força na América Latina no período. Apesar de ter desenvolvido seus estudos antropológicos sob a orientação do "pai da Antropologia Cultural", as propostas indigenistas de Manuel Gamio se mostram muito mais próximas de concepções higienistas e eugênicas do que do culturalismo de Franz Boas. Nos anos 40, quando se tornou diretor do I.I.I., "el Dr. Gamio” não apenas fazia parte da Sociedad Mexicana de Eugenesia para el Mejoramiento de la Raza, como "se ha[via] ubicado como una de las figuras más relevantes" da mesma "por su producción en la arqueología, antropología e impulso a las políticas indigenistas." Pouco tempo antes de publicar o referido editorial sobre o Dia do Índio em AI, ele havia publicado em Eugenesia, a revista da Sociedade Mexicana, um artigo em que exaltava a mestiçagem definindo-a em termos biológicos (raciais) como uma "adaptación al clima y geografia, a lo largo de vários siglos, por severo efecto de la selección natural.” (GAMIO, 1942, apud SUÁREZ Y LÓPEZ-GUAZO, 2009, p. 20)

Nesse sentido, dentro de sua proposta de "melhorar o desenvolvimento biológico" dos indígenas, se colocava muito claramente a ideia da mestiçagem. De fato, 
Gamio afirma exaustivamente nos editoriais de AI que os indígenas, na condição em que se encontravam, possuíam um "deficiente" ou "anormal" "desarrollo biológico." Em contraste, "desde el punto de vista biológico", o mestiço teria um desenvolvimento não apenas normal, mas, inclusive, biologicamente superior, pois seria possuidor "de las defensas naturales" tanto de indígenas quanto de europeus. (AI, vol. IV, n. 3, jul., 1944, p. 181; vol. V, n. 1, ene., 1945, p. 7; vol. XIV, n. 3, jul., 1954, p. 183)

Embora, até certo ponto, Gamio atribuísse caracteres culturais a sua definição de mestiço, ao afirmar, por exemplo, que "quienes presentam en mayor o menor proporción características culturales modernas, mezcladas con otras de origen precolombino y hablan el idioma nacional de sus respectivos países, son culturalmente mestizos" e isso "aun cuando por su aspecto físico corresponden al tipo indígena", a leitura do conjunto dos editoriais publicados em AI deixa patente que o processo de amálgama vislumbrado pelo diretor do I.I.I. não era simplesmente cultural, mas possuía uma inegável dimensão racial. Isso o levou, por exemplo, a defender a entrada massiva de imigrantes europeus nos países latino-americanos, após a Grande Guerra, como algo não apenas "humanitário", mas também "útil e benéfico" para intensificar o processo de mestiçagem na região. Para isso, defendia que deveriam ser aceitos somente os imigrantes que não "adolezcan de prejuicios raciales", caso contrário eles poderiam, em vez de ajudar, "entorpecer el mestizaje”, que, para Gamio, "e[ra] la mejor palanca con que esos países [americanos] podr[í]an forjar nacionalidades verdaderamente definidas y coerentes.” (AI, vol. XIV, n. 3, jul., 1954, p. 183; vol. VI, n. 1, ene., 1946, p. 3)

$\mathrm{Na}$ realidade, o grande objetivo do projeto indigenista de Gamio, que passava pela mestiçagem, era a formação de "verdadeiras nacionalidades", o que, em sua perspectiva, dependia de alcançar a homogeneização cultural e biológica de seus habitantes, projeto que comportava um inegável sentido evolucionista. Ao defender a homogeneização cultural, o diretor do I.I.I. se afastou das propostas de educação bilíngue para os indígenas, que era um tema bastante presente no continente, pelo 
menos desde os anos $30 .{ }^{16}$ Gamio, ao contrário, em seus editoriais de AI, defendeu que os indígenas fossem alfabetizados apenas na língua espanhola e argumentou, inclusive, que não seria necessário desenvolver programas governamentais específicos para esse fim. Num editorial de 1954, intitulado "Colaborando con la tarea de alfabetización", o diretor do I.I.I. argumentou que "ni gobiernos ni entidades particulares pueden disponer de las altas sumas que requeriría la publicación y distribución gratuita" de material específico para alfabetização indígena. Portanto, sugeriu que esse processo fosse desenvolvido através da reutilização de "revistas, opúsculos, publicaciones infantiles, belas ediciones dominicales de los periódicos [...] que cada día son arrojados al cesto [de basura] en las grandes ciudades." Em sua concepção, esse era um projeto viável cujo "éxito" dependia somente da ação de "personas dinámicas y altruístas" que organizassem a coleta nas grandes cidades e redistribuição nas zonas rurais dos impressos usados. Segundo o mesmo editorial, esse processo já estava sendo levado a cabo com grande sucesso no México, onde o próprio I.I.I. estava "enviando sus publicaciones sobrantes [...] al estado de Chiapas.” (AI, vol. XIV, n. 2, abr., 1954, p. 99-100)

Tal concepção absolutamente simplista do processo de alfabetização dos indígenas manifestada por Gamio dispensa comentários. Basta destacar que o "êxito" que ele esperava obter de tal iniciativa nunca chegou a efetivar-se, pelo menos não no caso já então iniciado do estado de Chiapas, que atualmente continua sendo um dos quais mais se falam as línguas indígenas no México e cuja trajetória histórica - que

\footnotetext{
${ }^{16}$ Para citar alguns exemplos significativos, destacamos o caso dos Estados Unidos, onde a instituição da educação bilíngue dos indígenas fez parte da ampla levada a cabo pelo comissário John Collier a partir de 1933 e que ficou consagrada no Indian Reorganization Act, de 1934, que alterou profundamente o histórico viés assimilacionista do indigenismo official estadunidense (ROBERTS Jr., p. 20-21); e o projeto do linguista William Townsend na Guatemala, que Moisés Sáenz conhece em 1931 e, a partir do qual, se "convierte, sorpresivamente, en el más portentoso prosélito del uso de la lengua indígena como instrumento de enseñanza", a ponto de, em 1934, establecer o mesmo projeto entre los nahuas de Morelos. (AGUIRRE BELTRÁN, 1981)
} 
chegou a dar origem ao EZLN $-{ }^{17}$, se distancia completamente da homogeneização cultural pretendida por Gamio, cuja visão evolucionista do desenvolvimento humano se manifestava até mesmo em relação ao passado indígena do continente. Para o antropólogo e arqueólogo, “en épocas precolombinas, la mayoría de los habitantes del Nuevo Continente vegetaban en inferiores etapas económico-culturales, exceptuándose a Mayas, Nahuas e Incas", que seriam superiores aos demais povos indígenas porque "habían alcanzado altos niveles en su modo de ser y vivir, como lo demuestran la tradición así como los grandes monumentos arquitectónicos y bellas esculturas que de ellos se conservan y aún hoy en día son dignas de admiración.” (AI, vol. XX, n. 1, ene., 1960, p. 3)

Gamio demonstra uma visão idealizada, que beira ao fetichismo, quando se refere aos elementos estéticos do passado mesoamericano, e muito particularmente a sua dimensão monumental. Mas, na leitura de seus editoriais em AI, não identificamos outros aspectos da história dessas mesmas civilizações, nem mesmo em seu passado “monumental”, capaz de despertar a admiração do antropólogo e arqueólogo mexicano. No mesmo editorial citado acima, Gamio defende que "lo conveniente para el progreso de los países indo-ibéricos es lograr que en sus poblaciones aumenten continua y progresivamente las características de la cultura moderna occidental", ainda que "se conserven y estimulen aquellas de origen precolombino y colonial que eran y siguen siendo de gran valor", leia-se: o senso estético indígena. Esta visão pode ser entendida como parte do que Alicia Azuela (2003) identificou como "anexação da arte" pelo discurso nacionalista mexicano pós-revolucionário. A construção ideológica nacionalista articulada por artistas e intelectuais ligados ao Estado - entre eles o próprio Gamio - se baseou na "suposta artisticidade nata do indígena", expressa em seu "passado artístico glorioso", que funcionava como um "recurso para fortalecer a singularidade nacional a partir da cultura." (AZUELA, 2003, p. 473)

\footnotetext{
${ }^{17}$ A respeito da trajetória de organização dos indígenas de Chiapas desde os anos 70 até o surgimento do EZLN, consultar: ANDREO (2013).
} 
Por mais que reconhecesse os valores estéticos da arte indígena do passado, e mesmo do presente, através do artesanato, nenhum outro âmbito da vida humana chegou a ser defendido pelo diretor do I.I.I. fora da cultura ocidental. No editorial de julho de 1953, por exemplo, Gamio volta a um dos temas mais presentes em seus artigos em AI, argumentando o seguinte em um texto sintomaticamente intitulado "Las tradiciones nocivas":

frecuentemente hemos asentado en esta Revista que la vida del indígena está presidida en mayor o menor grado por viejas tradiciones, o sea supervivencias psicológicas y culturales de origen precolombino y colonial, algunas de las cuales son benéficas, como sucede, por ejemplo, con su original patrimonio artístico. [...] Pero no nos referimos a ellas en esta ocasión porque es más urgente señalar y corregir las que son nocivas y desfavorables. (AI, v. VIII, n. 3, jul., 1953, p. 151)

Esse sentido prático, de "correção", atribuído à ação indigenista já havia sido expressamente colocado por Manuel Gamio logo que assumiu a direção do I.I.I. No primeiro texto que ele publicou em AI - um artigo assinado ao qual posteriormente remeteu os leitores de seus editoriais -, Gamio propôs uma classificação prática para se entender o grau de desenvolvimento das culturas indígenas, baseada na posse de objetos de cultura material pelas comunidades indígenas. $\mathrm{O}$ então novo diretor da instituição indigenista continental propunha que os indigenistas dos vários países americanos identificassem e catalogassem esses objetos atribuindo-lhes o caráter de "útil, deficiente o perjudicial", obviamente a partir de uma visão ocidental, cujo critério básico era a “eficácia." Sua proposta não tinha apenas o sentido teórico de uma catalogação, mas abarcava um objetivo prático de dimensões eminentemente autoritárias. No mesmo artigo, após desenvolver seus argumentos em torno do caráter dos objetos materiais indígenas, o diretor do I.I.I. instruiu os indigenistas a "aplicar los medios apropiados para extirpar o eliminar los objetos perjudiciales y perfeccionar los deficientes o sustituirlos por otros más eficaces." (AI, vol. II, n 3, jul., 1942, p. 18, grifos no original) 
Se a palavra "eficácia" nos remete a um vocabulário científico, e mesmo cientificista, seria impossível não remontar expressões como "extirpar”, "eliminar” e "substituir" à dinâmica colonial espanhola do século XVI, especialmente em suas manifestações durante a conquista do México. (GRUZINSKI, 2006) Dessa forma, o indigenismo de Manuel Gamio, então alçado à categoria de indigenismo oficial do I.I.I., apresentava-se exatamente sob a forma do que havia denunciado Moisés Sáenz ao abandar o paradigma da incorporação indígena:

\begin{abstract}
Somos unilaterales. Nos acercamos al indio como mexicanos, para imponerle una teoría nacional [...]. Vamos civilizar al indio, afirmamos. Eso es justamente lo que han proclamado todos los invasores "colonizadores" antes que nosotros. (SÁENZ, 2007 [1939], p. 144. Grifo no original)
\end{abstract}

\title{
Considerações finais
}

Ao contrário do que defende boa parte dos estudos acadêmicos realizados sobre Manuel Gamio ao longo do século XX, que identificam seu pensamento - e, muito especialmente sua crítica ao racialismo e seu elogio da mestiçagem - como bastante progressista e alinhado ao novo paradigma trazido pela Antropologia Cultural, trabalhos mais recentes, como, entre outros, o de Sergio Ricco, têm identificado Gamio como "un hombre de su tiempo que arrastra el positivismo decimonónico y lo acarrea hasta bien entrado el siglo XX." Nesse sentido, como destaca Ricco, "muy escuetas" foram "sus contribuciones a una teoría antropológica de carácter general e incluso de corte regional." (RICCO, 2015, p. 9)

Podemos identificar que existe em Gamio uma tensão entre os dois grandes paradigmas que marcaram sua formação: culturalismo e positivismo. Em sua atuação indigenista, o antropólogo e arqueólogo utilizou seletivamente elementos de ambos para pensar a questão indígena inserida em sua proposta central de legitimar um projeto nacional. O aparato discursivo com aparentes novas feições, que pretendia romper com os preconceitos e os princípios ideológicos que tinham sido marcantes durante a ditadura porfirista, ao final, ocultava velhas estruturas de dominação. 
Na realidade, o que mais chama a atenção na leitura dos editoriais de Ethnos, publicados nos anos 20, e América Indígena, publicados nas décadas de 1940 e 1950, é que não encontramos mudanças mais sistemáticas nas concepções do antropólogo e arqueólogo mexicano sobre o indigenismo em geral e a mestiçagem em particular, desde a publicação dos textos que foram reunidos em Forjando patria até sua morte, em 1960. Não obstante as imensas mudanças ocorridas no seio das teorias antropológicas ao longo de aproximadamente cinco décadas, os pressupostos básicos - notadamente evolucionistas - de sua percepção do indígena e sua relação com a nação mexicana e as nações latino-americanas mantiveram-se praticamente inabaláveis, bem como sua proposta indigenista de assimilação dos indígenas à nacionalidade por meio de um processo de mestiçagem que, ao fim e ao cabo, correspondia basicamente à ocidentalização.

Certamente, o fato de Manuel Gamio ter se mantido tanto tempo à frente do I.I.I. se relaciona com o perfil mais conservador com o qual a instituição se consolidou, apesar de seus inícios verdadeiramente progressistas. Desde sua origem, o Instituto teve uma trajetória intrinsecamente relaciona com a política externa estadunidense, cujos recursos financeiros sempre foram indispensáveis para a instituição. Tendo sido criado na época da política de "boa vizinhança" e inserido no contexto mais crítico que marcou esse momento - como mostra o apoio decisivo do governo estadunidense ao ousado projeto de Moisés Saénz ${ }^{18}$-, o I.I.I. acabou se consolidando, de fato, como uma instituição muito distante do papel de um verdadeiro questionamento ao status quo, dentro da qual cabia perfeitamente a direção de uma figura como a de Gamio, com sua pretensa "apolítica" gestão da instituição. Já em 1953, o I.I.I. tornou-se um organismo especializado da OEA, passando a vincular-se mais estreitamente com a conhecida política estadunidense para o continente durante a Guerra Fria.

\footnotetext{
${ }^{18}$ Vale destacar que não apenas John Collier, então comissário estadunidense de Assuntos Indígenas, era um grande entusiasta da Revolução Mexicana, como também várias outras figuras do círculo político de Franklin D. Roosevelt, incluindo o próprio presidente, nutriam verdadeira admiração pelas transformações decorrentes da Revolução de 1910 no México, muito particularmente em relação à questão agrária e as escolas rurais. Ver a respeito: AHLSTEDT, 2015.
} 


\section{Fontes e Referências Bibliográficas}

AGUILAR CAMÍN, Héctor \& MEYER, Lorenzo. À sombra da Revolução Mexicana. São Paulo: Edusp, 2000.

AGUILAR RIVERA, José Antonio. Moisés Sáenz y la escuela de la patria mexicana. Introducción a SÁENZ, Moisés. México Íntegro. México: Consejo Nacional para la Cultura y las Artes, 2007.

AGUIRRE BELTRÁN, Gonzalo. Crítica Antropológica: hombres e ideias. México: FCE, 1990. Instituto lingüístico de verano. América Indígena, vol. XLI, nº 3, jul., 1981.

AHLSTEDT, Wilbert Terry. John Collier and Mexico in the Shaping of U.S. Indian Policy: 1934-1945. Faculty of The Graduate College of the University of Nebraska, Lincoln, Nebraska, 2015 (Dissertation of Doctorate), 362 pág. Disponível em: https://digitalcommons.unl.edu/historydiss/82/ (acesso em 09/05/2018).

AZUELA DE LA CUEVA, Alicia. Arte y poder. México: FCE; El Colegio de Michoacán, 2003.

BÁEZ-JORGE, Félix. Antropología e Indigenismo en Latinoamérica: señas de identidad. La Palabra y el Hombre, n. 87, julio-septiembre, p. 17-38, 1993.

BÁEZ LANDA, Mariano. De indígenas a campesinos: miradas antropológicas de un quiebre paradigmático. Ruris, IFCH, Unicamp, v. 3, n. 2, pp. 55-74, set.09- fev.10.

BAUD, Michiel. Intelectuales y sus utopías: indigenismo y la imaginación de América Latina. Ámsterdam: CEDLA, 2003.

BONFIL BATALLA, Guillermo. México profundo: una civilización negada. México: SEP-CIESAS, 1987.

CASTILLO RAMÍREZ, Guillermo. Repensando críticamente los orígenes del indigenismo del Estado mexicano en el siglo X. Reconstrucción de los imaginarios de grupos indígenas y nación en Forjando Patria. In: SERRANO AVILES, Tomás; MONTOYA ARCE, B. Jaciel; JASSO SALAS, Pablo; MORENO JIMÉNEZ; Abigail (Coord.). La investigación social en México, México: Universidad Autónoma del Estado de Hidalgo, 2012, p. 31-44.

CASTRO, Celso (Org.). Franz Boas: Antropologia cultural. 2. ed. Rio de Janeiro: Jorge Zahar Ed., 2005. 
COSTA, Adriane Vidal; MAÍZ, Claudio (Org.). Nas tramas da "cidade letrada": sociabilidade dos intelectuais latino-americanos $\mathrm{e}$ as redes transnacionais. Belo Horizonte: Fino Traço, 2018.

CRESPO, Regina (Coord.). Revistas en América Latina: proyectos literarios, políticos y culturales. México: Eón; CIALC-UNAM, 2010.

DEL VAL, José (coord.); ZOLLA, Carlos. Documentos fundamentales del indigenismo. México: Universidad Nacional Autónoma de México, 2014.

DIAS, Natally Vieira. América Indígena e Boletín Indigenista: as publicações oficiais do Instituto Indigenista Interamericano e as vicissitudes da formação de uma rede intelectual transnacional em torno da instituição indigenista continental (1941-1945). In: COSTA, Adriane Vidal; MAÍZ, Claudio (Org.). Nas tramas da "cidade letrada": sociabilidade dos intelectuais latino-americanos $\mathrm{e}$ as redes transnacionais. Belo Horizonte: Fino Traço, 2018, p. 233-265.

FAVRE, Henri. El Indigenismo. México: FCE, 1998.

GAMIO, Manuel. Los prejuicios en Arqueología y Etnología. Anales del Museo Nacional de Arqueología, Historia y Etnología, Tomo V, n. 17, 1909-1915. Disponível em: $\quad$ https://mediateca.inah.gob.mx/islandora 74/islandora/object/articulo\%3A8090> (Acesso em 29/04/2020)

. Forjando Patria: pro-nacionalismo. México: Porrúa, 1916.

Revisión de las Constituciones de Latinoamericanas. Proceedings of the Second Scientific Congress, Washington, D. C., Government Printing Office, 1917. p. 374-377. Consideraciones sobre el problema indígena en América. América Indígena, v.

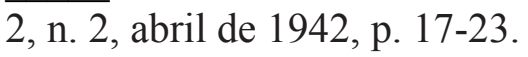

Algunas consideraciones sobre la Salubridad y la Demografía en México. Eugenesia. Tomo III; (28) febrero de 1942, p. 3-8.

GIL, Antônio Carlos Amador. Vozes indígenas na América: etnicidade e nação na América Latina contemporânea. Dimensões, NPIH/UFES, Vitória (ES), n.19, p. 11-26, 2007.

GIRAUDO, Laura. Celebrar a los indígenas, defender al indigenismo: el "Día del Indio" y el Instituto Indigenista Interamericano. In: Estudos Ibero-Americanos, Porto Alegre, vol. $43, \mathrm{n}^{\mathrm{o}} 1$, jan-abr, 2017, p. 82-97. 
. Neither "Scientific" nor "Colonialist": The Ambiguous Course of Inter-American Indigenismo in the 1940s. In: Latin American Perspectives, SAGE Publications California, vol. 39, n. 5, september, 2012, p. 12-32.

. Un campo indigenista transnacional y casi profesional: la apertura en Pátzcuaro (1940) de un espacio por y para los indigenistas. In: GIRAUDO, Laura; MARTÍN-SÁNCHEZ, Juan (eds.). La ambivalente historia del indigenismo: campo interamericano y trayectorias nacionales (1940-1970). Lima: IEP, 2011, p. 21-98.

GONZÁLEZ GAMIO, Ángeles. Manuel Gamio: padre de la antropología mexicana In: Gamio, Manuel. La población del Valle de Teotihuacán: representativa de las que habitan las regiones rurales del Distrito Federal y de los estados de Hidalgo, Puebla, México y Tlaxcala. Tomo I. Volumen primero. México: SEP, Instituto Nacional de Antropología e Historia, 2017, p. 15-21. 2003.

Manuel Gamio: una lucha sin final. México: Universidad Autónoma de México.

GRUZINSKI, Serge. A guerra das imagens: de Cristóvão Colombo a Blade Runner (1492-2019). São Paulo: Companhia das Letras, 2006.

INSTITUTO INDIGENISTA INTERAMERICANO. Acta Final del Primer Congreso Indigenista Interamericano. Pátzcuaro, Michoacán, México, 1940. Disponível em:

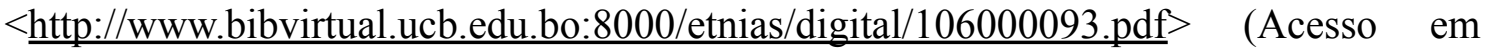
20/04/2020)

KOURÍ, Emilio. Manuel Gamio y el indigenismo de la Revolución Mexicana. In: ALTAMIRANO, Carlos (Dir.). Historia de los intelectuales en América Latina II: Los avatares de la "ciudad letrada" en el siglo XX. Buenos Aires: Katz Editores, 2010. p.419-432.

LEÓN-PORTILLA, Miguel. Manuel Gamio: Grandes Maestros. Revista de la Universidad Nacional de México, México, n. 429, octubre, p.22-26, 1986.

MATOS MOCTEZUMA, Eduardo. Introducción. In: Gamio, Manuel. Arqueología e Indigenismo. México, DF: SEP - Tentas, 1972. p.7-23.

MÉXICO. Secretaría de Agricultura y Fomento. Programa de la Dirección de Estudios Arqueológicos y Etnográficos. Oficina Impresora de la Secretaria de Hacienda, 1918.

RICCO MONGE, Sergio. Manuel Gamio Martínez entre México y América Latina: Indigenismo, nacionalismo y poder., Pacarina del Sur, año 7, n. 25, oct-dic, 2015. Disponível em: 
$<\underline{\text { http://pacarinadelsur.com/home/figuras-e-ideas/1217-manuel-gamio-martinez-entre-m }}$ exico-y-america-latina-indigenismo-nacionalismo-y-poder $>$ (Acesso em: 15/10/2019)

ROBERTS Jr., Preston. The Indian New Deal: and why it was needed. Pro Seminar, University of South Florida, 2010. Disponível em: $<$ http://legacy.usfsm.edu/academics/cas/capstone/2009-2010/history/roberts $\% 20$ $\% 20$ the $\% 20$ indian $\% 20$ new $\% 20$ deal $\% 20$ and $\% 20$ why $\% 20$ it $\% 20$ was $\% 20$ needed.pdf?fro $\underline{\mathrm{m}=404}>$ (Acesso em 10/03/2017).

RYLKO-BAUER, Barbara; SINGER, Merrill; VAN WILLIGEN, John. Reclaiming Applied Anthropology: Its Past, Present, and Future. American Anthropologist, vol. 108, $\mathrm{n}^{\mathrm{o}} .1,2006$, p. 178-190.

SÁENZ, Moisés. México Íntegro [1939]. México: Consejo Nacional para la Cultura y las Artes, 2007. 1933.

. Sobre el indio peruano y su incorporación al medio nacional. México: SEP,

SARLO, Beatriz. Intelectuales y revistas: razones de una práctica. In: América: Cahiers du CRICCAL, n. 9-10, 1992, p. 9-16.

SILVA, Cristhian Teófilo da. Indigenismo como ideologia e prática de dominação: apontamentos teóricos para uma etnografia do indigenismo latino-americano em perspectiva comparada. Latin American Research Review, v. 47, n. 1, pp. 16-34, 2012.

SOSNOWSKI, Saúl (ed.). La cultura de un siglo: América Latina en sus revistas. Buenos Aires: Alianza, 1999.

SUÁREZ Y LÓPEZ-GUAZO, Laura. Evolucionismo y Eugenesia en México. Boletín Mexicano de Historia y Filosofía de la Medicina. México, Sociedad Mexicana de Historia y Filosofía de la Medicina, vol. 12 (1), 2009, p. 19-23.

TODOROV, Tzveten. Nós e os Outros: a reflexão francesa sobre a diversidade humana. Rio de Janeiro: Jorge Zahar, 1993.

VILLORO, Luis. Los grandes momentos del indigenismo en México. 3. ed. México: FCE, COLMEX, El Colegio Nacional, 1996. 